\title{
New Records of Egg Parasitoids of Stink Bugs (Hemiptera: Pentatomidae) on Rice in Piauí, Brazil: Rate Parasitism, Incidence and Seasonality
}

\author{
Nadja N. P. Silva ${ }^{1 \pm=}$, Kátia K. A. Sousa ${ }^{1 \oplus}$, Paulo Henrique S. Silva ${ }^{2 \oplus}$, Ranyse B. Querino ${ }^{3 \oplus}$
}

\begin{abstract}
${ }^{1}$ Departamento de Proteção vegetal, Universidade Estadual Paulista "Júlio de Mesquita Filho", Botucatu, São Paulo, Brazil. ${ }^{2}$ Empresa Brasileira de Pesquisa Agropecuária (Embrapa Meio-Norte), Teresina, Piauí, Brazil. ${ }^{3}$ Empresa Brasileira de Pesquisa Agropecuária, Brasília, Distrito Federal, Brazil.

表=CCorresponding author: nadjanara.bio@gmail.com
\end{abstract}

Edited by: Regiane Cristina de Oliveira

Received: February 17, 2021. Accepted: May 31, 2021. Published: July 25, 2021.

\begin{abstract}
This study was conducted to investigate parasitism of naturally occurring pentatomid eggs in rice crops in a Cerrado-Caatinga ecosystem during the rainy and dry seasons in Teresina, Piauí, Brazil. Also, it provides information on the incidence and seasonality of parasitoid species. Parasitism was registered only during the rainy season, where Telenomus podisi (Ashmead, 1893) parasitized Oebalus poecilus (Dallas, 1851), Tibraca limbativentris (Stal, 1860) and Euschistus heros (Fabricius, 1798) eggs. Additionally, Trissolcus urichi (Crawford, 1913) was collected from $O$. poecilus and $T$. limbativentris eggs. Ooencyrtus anasae (Ashmead, 1887) was found in O. poecilus eggs. Such findings provide information that can be used to supplement the management of pentatomid pests in the rice agroecosystems, in Piauí, Brazil.
\end{abstract}

Keywords: Oryza sativa, Scelionidae species, Climatic factors, Natural biological control.

Rice (Oryza sativa L.) is one of the most cultivated and economically important agricultural crops worldwide, and Brazil is the largest producer and consumer outside Asia (Brazilian Rice 2020). Rice yields are affected by several biotic and abiotic factors being insect-pests the major threat once they cause considerable crop losses.

Stink bugs (Hemiptera: Pentatomidae) are economically significant rice insect-pests in Brazil (Ferreira et al. 2001). Among them, pentatomids have a wide range of species registered in rice crop that can potential cause losses up to $80 \%$ during high infestations (Ferreira \& Barrigossi 2006). An important tool for the management of pentatomids species complex is the use of egg parasitoids (Koppel et al. 2009; Laumann et al. 2010). However, investigations about these parasitoids that naturally attack stink bug eggs in rice have only now begun in Brazil.

An essential step to use these natural enemies in biological control programs is to collect and identify the species of pentatomid egg parasitoids in rice production systems. In addition, the influence of climate variables such as temperature, humidity, and precipitation, on the development and diversity of these stink bugs and parasitoids in this crop must also be determined. Thus, this study provides new records, with information on the incidence and seasonality, of egg parasitoid species from stink bugs in rice crops located in the state of Piauí, Brazil.

Data were collected weekly from rice crops in the experimental area of Embrapa Meio-Norte in Teresina, Piauí, Brazil (05 02' 21.36" $\mathrm{S}, 42^{\circ} 47^{\prime} 22.44^{\prime \prime} \mathrm{W}$ ), during the rainy (Februarry-May) and dry (JulyOctober) seasons in 2015. The study area is situated in a humid tropical climate, with two climatic seasons the rainy season and the dry season (Köppen Aw' climate classification). The vegetation in this area was composed of Cerrado (tropical savanna) forests and Caatinga (dry forest) (Bastos \& Andrade Jr 2008). Rice crops planting systems were irrigated by controlled flooding, in lowland soils, during and dry seasons and upland rice, in cerrado soils, during the rainy seasons

Stink bug eggs were collected directly from the leaves through visual inspection of the plants. The samples were chosen randomly to obtain the greatest possible diversity. Collected egg masses were placed individually in small glass tubes and remained under controlled conditions ( $25 \pm 2{ }^{\circ} \mathrm{C}, \mathrm{RH} 70 \pm 10,12: 12 \mathrm{~h} \mathrm{~L}$ : D photoperiod) until the parasitoids or immatures stink bugs emerged. The emerged parasitoids were preserved in $70 \%$ alcohol for further identification.

The parasitoid species were identified according to Johnson (1984a, 1984b, 1985, 1987a, 1987b), Masner (1976) and Talamas et al. (2015). The voucher specimens were deposited in the insect collection at Embrapa Meio-Norte in Teresina, Piauí, Brazil.

To verify the influence of the climatic factors on the occurrence of stink bugs and egg parasitoids populations, a Pearson correlation analysis was performed $(P<0.05)$ using average monthly maximum and minimum temperatures $\left({ }^{\circ} \mathrm{C}\right)$, average percent of monthly relative humidity (\%), and monthly accumulated precipitation $(\mathrm{mm})$ data from the Climate Station at the National Meteorology Institute (INMET), located in the experimental area. In addition, correlation was made between of eggs parasitoids population and the number of stink bug egg masses collected in rice crops. Data analyses were performed using the InfoStat software (Di Rienzo et al. 2011).

Parasitism was recorded in three species of Pentatomidae: Oebalus poecilus (Dallas, 1851), Tibraca limbativentris (Stal, 1860), and Euschistus heros (Fabricius, 1798). The species of egg parasitoids identified were Telenomus podisi (Ashmead, 1893), Trissolcus urichi (Crawford, 1913), and Ooencyrtus anasae (Ashmead, 1887) (Tab. 1).

Telenomus podisi was the most frequent and abundant species (Tab. 1). Trissolcus urichi was registered parasitizing eggs of $O$. poecilus and T. limbativentris (Tab. 1). Ooencyrtus anasae presented a sporadic occurrence compared to the other species being found in $O$. poecilus eggs (Tab. 1).

The parasitism of $O$. anasae in $O$. poecilus eggs and $T$. podisi in $E$. heros eggs in rice crops reported in this study are unheard. Previously, only the parasitism of $T$. podisi in E. heros eggs in other host plants, such as soybean had been reported (Pacheco \& Corrêa-Ferreira 2000). In addition, this was the first report of stink bug egg parasitoids in rice crops in the state of Piauí. Previously, there were reports of egg parasitism in other phytophagous bugs and/or host plants in this state. Telenomus podisi was reported to parasitize Piezodorus guildinii 
(Westwood, 1837), Nezara viridula (Linnaeus, 1758), and E. heros eggs in soybeans and P. guildinii in beans (Paz Neto et al. 2015; Sousa et al. 2019).

Table 1. Parasitism of stink bug eggs collected from rice in the Teresina, state of Piauí, Brazil.

\begin{tabular}{|c|c|c|c|c|}
\hline \multirow{2}{*}{ Stink bug species } & \multicolumn{2}{|c|}{ Number of postures } & \multirow{2}{*}{ Parasitoids species } & \multirow{2}{*}{$\begin{array}{c}\text { Parasitism } \\
\text { (\%) }\end{array}$} \\
\hline & Collected & Parasitized & & \\
\hline \multirow{3}{*}{ Oebalus poecilus } & \multirow{3}{*}{53} & 18 & Telenomus podisi & 33.96 \\
\hline & & 5 & Trissolcus urichi & 7.55 \\
\hline & & 2 & Ooencyrtus anasae & 3.77 \\
\hline \multirow[b]{2}{*}{ Tibraca limbativentris } & \multirow[b]{2}{*}{7} & 4 & Telenomus podisi & 80 \\
\hline & & & Trissolcus urichi & \\
\hline Euschistus heros & 1 & 1 & Telenomus podisi & 100 \\
\hline
\end{tabular}

Telenomus and Trissolcus are the most important genus of Pentatomidae parasitoids in rice agroecosystems in Brazil (Maciel et al. 2007; Riffel et al. 2010; Farias et al. 2012; Idalgo et al. 2013). Trissolcus urichi has been reported parasitizing T. limbativentris eggs in the states of Maranhão, and Santa Catarina(Maciel et al. 2007; Riffel et al. 2010) and $O$. poecilus eggs in the state of Maranhão (Melo Neto et al. 2020).

Telenomus podisi is the parasitoid mostly associated with Hemiptera (Zerbino \& Panizzi 2019). In rice, this parasitoid has been registered in T. limbativentris eggs (Maciel et al. 2007; Riffel et al. 2010; Idalgo et al. 2013), Glyphepomis adroguensis Berg, 1891 (Farias et al. 2012), and O. poecilus (Margaría et al. 2009; Melo Neto et al. 2020). As for $O$. anasae, its occurrence is reported in other crops of agricultural importance (Paz-Neto et al. 2015) where it is an important biological control agent for stink bugs.
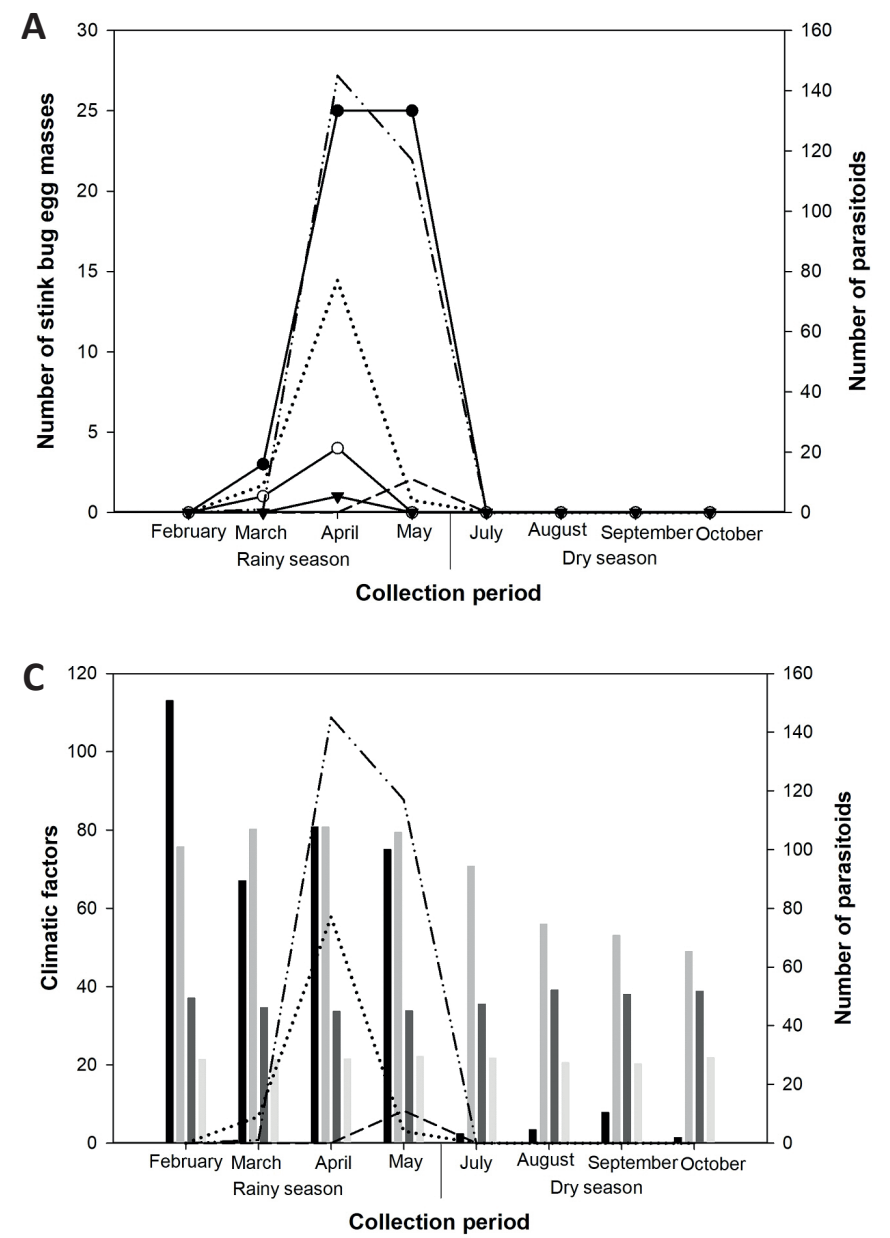

The occurrence of stink bug and eggs parasitoids in rice was registered only during the rainy season (Fig. 1), when the abundance of these stink bug was negatively correlated with maximum temperature $(r=-0.77 ; P<0.05)$ and was positively correlated with minimum temperature $(r=0.43 ; P>0.05)$, precipitation $(r=-0.50 ; P>0.05)$ and relative humidity $(r=0.61 ; P>0.05)$. The abundance of these egg parasitoids was negatively correlated with maximum temperature $(r=-0.8 ; P>0.05)$ and precipitation $(r=-0.32 ; P>0.05)$. There were positive correlations with minimum temperature $(r=0.39 ; P>0.05)$ and relative humidity $(r=0.62 ; P>0.05)$. The number of egg parasitoids was positively correlated with the number of stink bugs $(r=0.98 ; P<$ 0.05).

The occurrence of these stink bugs and species of egg parasitoids in rice crops only in the rainy season demonstrates that this season are more suitable for the development and survival of these insects, when compared to the dry season, due to the extreme climatic factors such as high temperature and low humidity, in the dry season (Fig. 1). Similar results were found by Sousa et al. (2019) where climatic conditions were more favorable for abundant hemipteran and egg parasitoids in bean crops during the rainy season at the same region of our study.

Our results contribute to advance the knowledge about stink bug egg parasitoids and their seasonality, thereby providing additional support for the natural biological control programs of stink bugs complex in the rice agroecosystems in Brazil.

\section{Acknowledgements}

The National Council for Scientific and Technological Development (CNPq) supported this study (No. 456197/2014-1). We are also grateful for valuable comments on the manuscript from anonymous reviewers and the editor of the journal.

\section{Authors' Contributions}
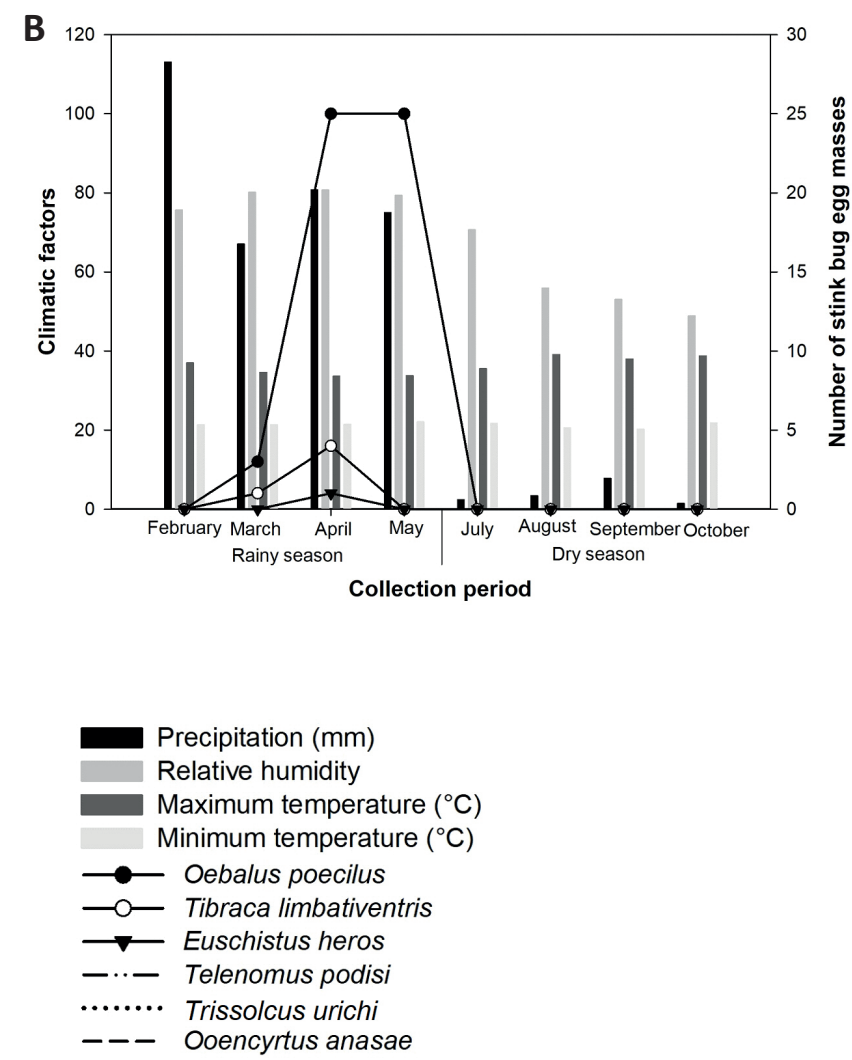

Figure 1. Incidence of egg parasitoids and stink bugs in rice crops during the wet and dry seasons, in Teresina, Piauí, Brazil (2015). (A) Fluctuation of stink bugs and parasitoids species in the seasons. (B) Stink bugs species and climatic factors. (C) Egg parasitoids species and climatic factors. 
NNPS and KKAS performed the data collection. NNPS reviewed the literature and wrote the manuscript. RBQ contributed to the taxonomic identification of eggs parasitoids. PHSS and RBQ contributed to the revisions and adding content to the manuscript.

\section{References}

Bastos, E. A.; Andrade Jr., A. S. (2008) Boletim agrometeorológico de 2007 para o Município de Teresina, Piauí. Teresina: Embrapa MeioNorte.

Brazilian Rice (2020) http://brazilianrice.com.br. Access on: 08.xii.2020.

Di Rienzo, J. A.; Casanoves, F.; Balzarini, M. G.; González, L.; Tablada, M.; Robledo, Y. C. (2011) InfoStat versión 2011. Grupo InfoStat, FCA, Universidad Nacional de Córdoba, Argentina. http://www. infostat.com.br

Farias, P. M.; Klein, J. T.; Sant' Ana, J.; Radaelli, L. R.; Grazia, J. (2012) The first records of Glyphepomis adroguensis (Hemiptera, Pentatomidae), and its parasitoid, Telenomus podisi (Hymenoptera, Platygastridae), on irrigated rice fields in Rio Grande do Sul, Brazil. Revista Brasileira de Entomologia, 56(3): 383-384. doi: 10.1590/ S0085-56262012005000044

Ferreira, E.; Barrigossi, J. A. F. (2006) Produção e qualidade do grão do arroz irrigado infestado por adultos de percevejo-das-panículas. Pesquisa Agropecuária Brasileira, 41(7): 1083-1091. doi: 10.1590/ S0100-204X2006000700003

Ferreira, E.; Breseghello, E. F.; Castro, M.; Barrigossi, J. A. F. (2001) Broca-do-colmo nos agroecossistemas de arroz do Brasil. Goiânia: Embrapa Arroz e Feijão. Documentos.

Idalgo, T. D. N.; Sant' Ana, J.; Redaelli, L. R.; Pires, P. D. S. (2013) Parasitismo de ovos de Tibraca limbativentris Stal (Hemiptera: Pentatomidae) em lavoura de arroz irrigado, Eldorado do Sul, RS. Arquivos do Instituto Biológico, 80(4): 453-456. doi: 10.1590/ S1808-16572013000400014

Johnson, N. F. (1984a) Systematics of Nearctic Telenomus: classification and revisions of the podisi and phymatae species groups (Hymenoptera: Scelionidae). Bulletin of the Ohio Biological Survey, 6 (3): 1-113.

Johnson, N. (1984b) Revision of the Nearctic species of the Trissolcus flavipes group (Hymenoptera: Scelionidae). Proceedings of the Entomological Society of Washington, 86(4): 797-807.

Johnson, N. (1985) Systematics of New World Trissolcus (Hymenoptera: Scelionidae) species related to T. basalis. The Canadian Entomologist 117(4): 431-445.

Johnson, N. (1987a) Systematics of New World Trissolcus, a genus of pentatomid egg-parasites (Hymenoptera: Scelionidae): Neotropical species of the flavipes group. Journal of Natural History, 21(2): 285304.

Johnson, N. (1987b) The Neotropical telenomine genus Phanuropsis Girault (Hymenoptera: Scelionidae). Annals of the Entomological Society of America, 80(5): 660-663.

Koppel, A. L.; Herbert Jr, D. A.; Kuhar, T. P.; Kamminga, K. (2009) Survey of stink bug (Hemiptera: Pentatomidae) egg parasitoids in wheat, soybean, and vegetable crops in southeast Virginia. Environmental Entomology, 38(2): 375-379. doi: 10.1603/022.038.0209

Laumann, R. A.; Moraes, M. C. B.; Silva, J. P. D.; Vieira, A. M. C.; Silveira, S. D.; Borges, M. (2010) Egg parasitoid wasps as natural enemies of the neotropical stink bug Dichelops melacanthus. Pesquisa Agropecuária Brasileira, 45(5): 442-449. doi: 10.1590/S0100204X2010000500002

Maciel, A. A. S.; Lemos, R. N. S.; Souza, J. R.; Costa, V. A.; Barrigossi, J. A. F.; Chagas, E. F. (2007) Parasitismo de ovos de Tibraca limbativentris Stal (Hemiptera: Pentatomidae) na cultura do arroz no Maranhão. Neotropical Entomology, 36(4): 616-618. doi: 10.1590/S1519$566 \times 2007000400023$

Margaría, C. B.; Loiacono, M. S.; Lanteri, A. A. (2009) New geographic and host records for scelionid wasps (Hymenoptera: Scelionidae) parasitoids of insect pests in South America. Zootaxa, 2314: 41-49. doi: 10.11646/zootaxa.2314.1.2

Masner, L. (1976) Revisionary notes and keys: New World genera of
Scelionidae (Hymenoptera: Proctotrupoidea). Memoirs of the Entomological Society of Canada, 108(S97): 1-87.

Melo Neto, A. J.; Souza, J. R.; Santiago, C. M.; Pereira, F. A. D. S.; Lima, M. H.; Wengrat, A. P. D. S. (2020) Primeiro registro de parasitoides de ovos de Oebalus poecilus (Dallas, 1851) (Hemiptera: Pentatomidae) em arroz no Maranhão, Brasil. Entomological Communications, 2: ec02032. doi: 10.37486/2675-1305.ec02032

Pacheco, D. J.; Corrêa-Ferreira, B. S. (2000) Parasitismo de Telenomus podisi Ashmead (Hymenoptera: Scelionidae) em populações de percevejos pragas da soja. Anais da Sociedade Entomológica do Brasil, 29(2): 295-302. doi: 10.1590/S0301-80592000000200011

Paz-Neto, A. A.; Querino, R. B.; Margaría, C. B. (2015) Egg parasitoids of stink bugs (Hemiptera: Coreidae and Pentatomidae) on soybean and cowpea in Brazil. Florida Entomologist, 98(3): 929-932. doi: 10.1653/024.098.0318

Riffel, C. T.; Prando, H. F.; Boff, M. I. (2010) Primeiro relato de ocorrência de Telenomus podisi (Ashmead) e Trissolcus urichi (Crawford) (Hymenoptera: Scelionidae) como parasitóides de ovos do percevejo-do-colmo-do-arroz, Tibraca limbativentris (Stal) (Hemiptera: Pentatomidae), em Santa Catarina. Neotropical Entomology, 39(3): 447-448. doi: 10.1590/S1519$566 \times 2010000300021$

Sousa, K. K. A.; Silva, N. N. P.; Querino, R. B.; Silva, P. H. S.; Grazia, J. (2019) Diversity, seasonality, and egg parasitism of Hemipteran (Coreidae and Pentatomidae) from a cowpea crop in Northeastern Brazil. Florida Entomologist, 102(1): 29-35. doi: 10.1653/024.102.0105

Talamas, E. J.; Johnson, N. F.; Buffington, M. (2015) Key to Nearctic species of 418 Trissolcus Ashmead (Hymenoptera, Scelionidae), natural enemies of native and invasive stink bugs (Hemiptera, Pentatomidae). Journal of Hymenoptera Research, 43: 45-420. doi: 10.3897/JHR.43.8560

Zerbino, M. S.; Panizzi, A. R. (2019) The underestimated role of pentatomid parasitoids in Southern South America. ArthropodPlant Interactions, 13(5): 703-718. doi: 10.1007/s11829-01909703-1 